\title{
Mersin Yöresi Saf Kızılçam (Pinus brutia Ten.) Meşcerelerinde Tek Girişli Odun Ürün Çeşitleri Tablosunun Düzenlenmesi
}

\author{
Abdurrahman ŞAHİ**1, Turan SÖNMEZ ${ }^{2}$, Aydın KAHRIMAN ${ }^{1}$ \\ ${ }^{1}$ Artvin Çoruh Üniversitesi Orman Fakültesi, 08000, Artvin, Turkey \\ ${ }^{2}$ Bursa Teknik Üniversitesi Orman Fakültesi, 16330, Artvin, Turkey \\ * Corresponding Author: asahin84@windowslive.com
}

Geliş Tarihi: 22.06.2016

Kabul Tarihi: 13.12 .2016

Özet: Bu çalışmada, Mersin Orman Bölge Müdürlüğü sınırları içinde yer alan saf ve doğal Kızılçam meșcereleri için 'Odun Ürün Çeşitleri Tablosu' düzenlenmesi amaçlanmıştır. Bu amaçla, 488 adet Kızılçam ağacı kesilmiş ve bu ağaçlardan elde edilebilecek odun ürün çeşitleri olan tomruk, maden direği, sanayi odunu ve kabuk oranları belirlenmiş̧tir. Sonra bu oranlar göğüs çapı ile ilişkiye getirilerek regresyon modelleri elde edilmiştir. Bu modellerin kullanılmasıyla da Kızılçam için ‘Tek Girişli Odun Ürün Çeşitleri Tablosu' oluşturulmuştur. Çalışma kapsamında elde edilen modellere ilişkin belirtme katsayıları $\left(\mathrm{R}^{2}\right)$ ve standart hatalar $\left(S_{y . x}\right)$ sırasıyla; tomruk için 0.840 ve 6.771 ; sanayi odunu için 0.700 ve 7.500 ; maden direği için 0.856 ve 10.941 ve kabuk için de 0.972 ve 0.401 olarak hesaplanmıştır.

Anahtar Kelimeler: Odun ürün çeşitleri tablosu, Kızılçam, Mersin

\section{Single entry Raw Wood Products Table Construction For Calabrian pine (Pinus brutia Ten.) in Mersin Region}

Abstract: The main purpose of this study was to construct 'Raw Wood Products Table' for the pure and nature Calabrian pine stands within the border of Mersin Regional Directorate of Forestry. For this purpose, 488 sample trees were cut and raw wood products which can be obtained as log, mine prop, industrial wood and bark volume ratios were determined. Then, regression models were obtained with relationship of these ratios and diameter at breast. 'Single-Entry Raw Wood Products Table' were created by using these models. The coefficient of determination $\left(\mathrm{R}^{2}\right)$ and standard error were respectively 0.840 and 6.771 for $\log ; 0.700$ and 7.500 for industrial wood; 0.856 and 10.941 for mine prop and 0.972 and 0.401 for bark.

Keywords: Raw wood products table, Calabrian pine, Mersin

\section{Giriş}

K1z1lçam (Pinus brutia Ten.) 5610215 ha (ülke ormanlarının \%25.11'i) ile (Şekil 1) ülkemizde en fazla yayılışa sahip iğne yapraklı türümüzdür (Anonim, 2015). Kızılçam, genel coğrafi yayılışını Doğu Akdeniz Havzası'nda (Asmaz, 1993), özellikle de Türkiye'de yapmaktadır (Anşin, 1994). Ülkemizde bu denli öneme sahip olan bir Kızılçamın odun üretimi ise $5140007 \mathrm{~m}^{3}$ yapacak ve $1055335 \mathrm{~m}^{3}$ yakacak olmak üzere ilk sıradadır (URL1). Dolayısıyla en çok üretimi yapılan Kızılçam odununa ilişkin ürün çeşitlerinin bilinmesi de, bu türün yayılışı kadar önemli ve gereklidir.

Orman ürünleri; yükte ağır pahada hafif, taşınması ve depolanması güç olup kullanım alanı oldukça geniş ve ikame edilebilir özelliktedirler. Sahip oldukları önemden dolayı da, orman ürünlerinin fiyatı; türüne, yöresine ve mevsimine göre farklılik göstermektedir. Zira orman ürünleri, nüfus artışıyla orantılı olarak arttırılamayacağı için, fiyatları sürekli olarak yükseliş göstermektedir (Kalıpsız, 1982). Bu sebeple orman ürünlerinin çeşitlerini ve miktarlarını doğru şekilde tespit etmek, gerek orman yöneticiler ile planlayıcılar ve gerekse araştırmacılar açısından oldukça önemlidir.

Hâlihazırda kullanılmakta ve üretilmeye devam edilmekte olan ağaç hacim tabloları, dikili gövde odununa ilişkin hacim değerlerini verirken; ağaca ilişkin ayrıntılı tahminlere imkân verememekte ve yetersiz kalmaktadırlar. Çünkü günümüzde yalnızca ağaçların odun servetlerinin bilinmesi yeterli olmamakta; işletmelerin ekonomik açıdan kâr oranlarını arttırmak için üretilen odun ürün çeşitlerinin ve kalitesinin de doğru bir şekilde saptanmasını gerektirmektedir. $\mathrm{Bu}$ bağlamda odun ürün çeşitlerinin bilinmesiyle, 
ormanlarımızda yapılacak olan planlara fayda sağlanacağı, ayrıca ekonomik fonksiyonlu planlamaya da önemli bir katkıda bulunulacağı düşünülmektedir (Şahin, 2015).

Kullanım durumuna göre odunlar 'Yapacak Odunlar' ve 'Yakacak Odunlar' olmak üzere ikiye ayrılmaktadır. Yapacak odunlar yuvarlak odunlar olup çeşitleri; tomruk, direk, yuvarlak sanayi odunu, sirık ve çubuktur. Sun ve ark (1978)'nın da belirttiği gibi, özellikle parasal değerleri ve kullanım yerleri birbirinden önemli derecede farklı olan bu odun ürün çeşitlerinin, tek ağaç ve hektardaki dağılımlarının önceden bilinmesi ile birbirinin yerine konulmasindan doğabilecek önemli zararlar önlenebilecektir.

Ülkemizde, ürün çeşitlerinin belirlenmesine ilişkin yapılan çalışmalar oldukça sinırlıdır. Sun ve ark. (1978) yaptıkları çalışmada ülkemizdeki temel ağaç türlerimiz (Kızılçam, Karaçam, Sarıçam, Göknar, Sedir, Kayın) için; ağaç hacim tabloları oluşturmanın yanısıra, ilgili ağaç türleri için, tek ağaç ve birim alan bazında ürün çeşidi ve kabuk oranlarını saptamış, ayrıca tek ağaç ürün çeşidi hacim oranları için tek girişli tablolar ve çok girişli modeller oluşturmuştur. $\mathrm{Bu}$ çalışmaların ardından, Asan (1984), yaptığg çalışmada Kazdağ Göknarı için tek ağaç ürün çeşitleri tablosu düzenlemiştir. Bunlardan ayrı olarak, Yeşil (1992) çalışmasında; Sun ve ark. (1978) tarafından yapılan araştırmadaki modeli kendi verilerine uygulamak suretiyle, Kızılçamda ürün çeşitleri tablosu hazırlamıştır.

$\mathrm{Bu}$ çalışmada da, ülkemizde yöresel bir odun ürün çeşitleri tablosunun olmayış1 dikkate alınarak, Mersin Yöresi saf Kızılçam meşcereleri için tek girişli odun ürün çeşitleri tablosu düzenlenmiştir. Ayrıca çalışma kapsamında üretilen tek girişli modeller, Sun ve ark. (1978) tarafindan yapılmış olan modellerle de karşılaştırılmıştır.

\section{Materyal ve Metot}

Mersin ili coğrafi olarak $36^{\circ}-37^{\circ}$ kuzey enlemleri ile $33^{\circ}-35^{\circ}$ doğu boylamları arasında, Orta Akdeniz Bölgesinde yer almakta olup, kuzeyinde Karaman ve Konya illeri, doğusunda Adana ili, güneyinde Akdeniz, batısinda ise Antalya ili bulunmaktadır. Çalışma alanı olan Mersin ilinde, Akdeniz iklimi görülmekte; yazlar sıcak ve kurak, kışlar ise 1 lık ve yağışlı geçmektedir. Mersin ilinin yıllık ortalama yağgş miktarı $585.4 \mathrm{~kg} / \mathrm{m}^{2}$ ve yıllık ortalama sicaklığ 1 ise $19.1^{\circ} \mathrm{C}$ dir (URL2). Çalışma alanı (Şekil 1) olan Mersin Orman Bölge Müdürlüğ̈̈’nün, yüzölçümü 1563068 ha olup bu alanın 840470 ha'1 (\%53.77'si) ormanlık; bunun da 357352.2 ha'1 (yaklaşık \%42.5'i) Kızılçam meşcerelerinden oluşmaktadır (Anonim, 2015).

$\mathrm{Bu}$ çalışmada, TÜBİTAK tarafindan desteklenen, "Antalya ve Mersin Yöresi Saf Kızılçam Meşcerelerinde Hasılat Araştırmaları" adlı proje kapsamında, Mersin Yöresinden kesilmiş olan 488 adet ağaçtan elde edilen veriler kullanılmıştır (Kahriman ve ark., 2016). Söz konusu ağaçlar, ilgili proje kapsamında, Şahin (2015) tarafından hazırlanan doktora tezi için alınmış 243 örnek alanı temsilen kesilmişlerdir. Örnek alanların dağılım ve konumlarının belirlenmesinde farklı yaş sınıfı, bonitet ve sıklık derecelerine sahip olmaları dikkate alınmıştır. Bu amaçla her bir örnek alandan biri orta ağacı temsil eden ağaç ve diğeri üst boyu temsil eden ağaç olmak üzere toplamda 2 ağaç kesilmiştir. Aynı zamanda bu ağaçların, farklı çap ve boy kademelerinde, canlı, sağl1klı, tek gövdeli ve sağlam tepeli olmalarına da dikkat edilmiştir. Bir ağaçtan elde edilebilecek odun ürünü çeşitlerini belirleyebilmek için ağaç dipten tepeye doğru 2 m'lik seksiyonlara ayrılmış, her seksiyonun dip ve uç çapı kabuklu ve kabuksuz olarak ölçülmüş ve bu kısımdan hangi ürünün elde edilebileceği kayıt altına alınmıştır. Çalışmada kullanılan örnek ağaçların çap ve boy basamaklarına dağılımı Tablo 1'de ve bu ağaçlara ilişkin istatistiksel bilgiler de Tablo 2'de verilmiştir. Ürün çeşitlerinin belirlenmesinde orman ürünleri standardizasyonu (Tablo 3) (Günay ve Çancı, 1982), hacimlendilirmesinde ise Smalian, silindir ve koni formülleri kullanılmıştır. 


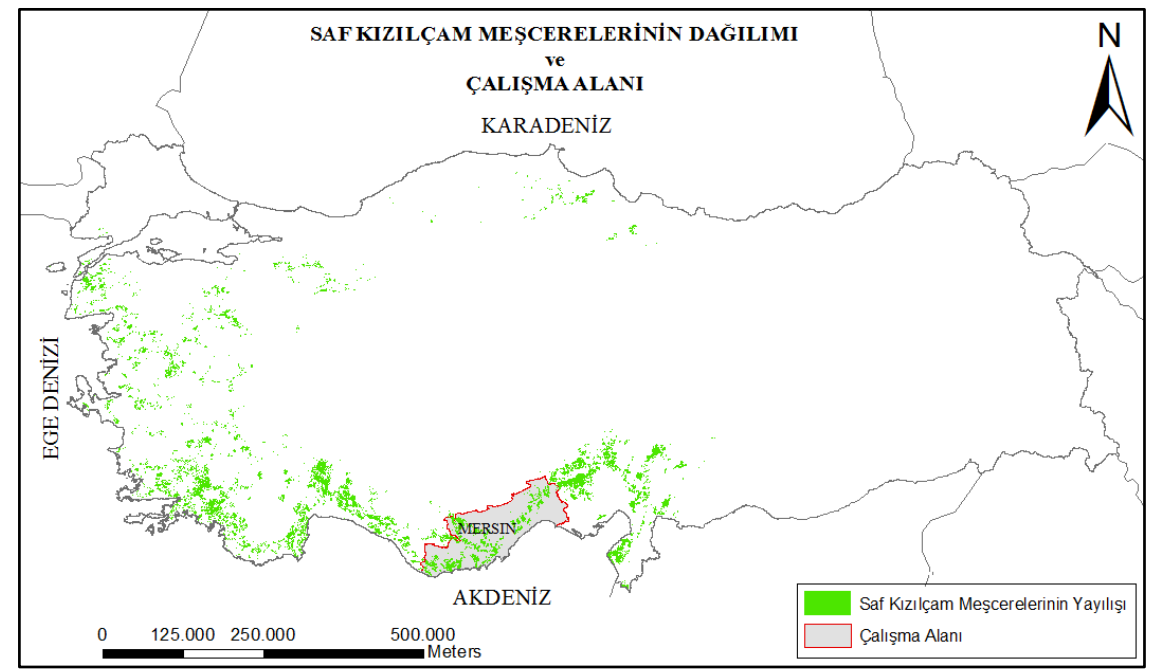

Şekil 1. Saf Kızılçam meşcerelerinin ülkemizdeki yayılışı ve çalışma alanı

Tablo 1. Örnek ağaçların çap ve boy basamaklarına dağılımı

\begin{tabular}{|c|c|c|c|c|c|c|c|c|c|c|c|c|c|c|c|c|c|c|}
\hline \multirow{2}{*}{$\begin{array}{l}\text { Çap } \\
\text { Bas. } \\
(\mathrm{cm})\end{array}$} & \multicolumn{17}{|c|}{ Boy Basamakları (m) } & \multirow[b]{2}{*}{$\Sigma$} \\
\hline & 1 & 3 & 5 & 7 & 9 & 11 & 13 & 15 & 17 & 19 & 21 & 23 & 25 & 27 & 29 & 31 & 33 & \\
\hline 2 & 7 & 18 & & & & & & & & & & & & & & & & 25 \\
\hline 6 & & 4 & 10 & 4 & & & & & & & & & & & & & & 18 \\
\hline 10 & & 3 & 5 & 9 & 13 & & & & & & & & & & & & & 30 \\
\hline 14 & & & 6 & 6 & 31 & 12 & 1 & & & & & & & & & & & 56 \\
\hline 18 & & & & 2 & 9 & 16 & 9 & 4 & 1 & 1 & & & & & & & & 42 \\
\hline 22 & & & & & 2 & 10 & 16 & 7 & 4 & 2 & 3 & 3 & & & & & & 47 \\
\hline 26 & & & & & 1 & 7 & 4 & 17 & 11 & 8 & 6 & 2 & 2 & 1 & 1 & & & 60 \\
\hline 30 & & & & & & 1 & 5 & 13 & 9 & 6 & 10 & 7 & 3 & & & & & 54 \\
\hline 34 & & & & & & & 3 & 5 & 7 & 11 & 6 & 10 & 4 & 1 & 3 & & & 50 \\
\hline 38 & & & & & & & & 5 & 10 & 4 & 5 & 8 & 2 & 1 & 1 & & & 36 \\
\hline 42 & & & & & & & & 2 & 4 & 4 & 8 & 3 & 1 & 1 & 5 & & & 28 \\
\hline 46 & & & & & & & & & 2 & 1 & 2 & 2 & 3 & 1 & 1 & & 1 & 13 \\
\hline 50 & & & & & & & & & & 3 & 4 & 2 & 2 & 1 & 1 & & & 13 \\
\hline 54 & & & & & & & & & & & 1 & 2 & 3 & & & & & 6 \\
\hline 58 & & & & & & & & & & & 2 & 1 & & 1 & & & & 4 \\
\hline 62 & & & & & & & & & & & 2 & & 1 & 1 & 1 & & & 5 \\
\hline 66 & & & & & & & & & & & & & & 1 & & & & 1 \\
\hline$\sum$ & 7 & 25 & 21 & 21 & 56 & 46 & 38 & 53 & 48 & 40 & 49 & 40 & 21 & 9 & 13 & - & 1 & 488 \\
\hline
\end{tabular}

Tablo 2. Örnek ağaçlara ilişkin çeşitli istatistiksel bilgiler

\begin{tabular}{ccccc}
\hline Değişken & Minimum & Maksimum & Ortalama & Standart Sapma \\
\hline Göğüs Çapı $(\mathrm{cm})$ & 0.7 & 64.1 & 25.9 & 13.3 \\
Boy $(\mathrm{m})$ & 1.5 & 33.9 & 14.9 & 6.8 \\
Yaş (yıl) & 5 & 165 & 54.7 & 37.2 \\
Kabuksuz Hacim $\left(\mathrm{dm}^{3}\right)$ & 0.9 & 3075.2 & 430.2 & 504.0 \\
Kabuklu Hacim $\left(\mathrm{dm}^{3}\right)$ & 1.2 & 3697.9 & 530.8 & 611.1 \\
\hline
\end{tabular}


Tablo 3.Yuvarlak odunların Türk standartlarına göre sınıflandırılması (Günay ve Çancı, 1982)

\begin{tabular}{cccccc}
\hline Sinıflar & $\begin{array}{c}\text { Orta çap } \\
\text { (kabuksuz, cm) }\end{array}$ & Boy (m) & Sınıflar & $\begin{array}{c}\text { Orta çap } \\
(\text { kabuklu, cm })\end{array}$ & Boy (m) \\
\hline Tomruk & $\geq 19$ & $\geq 1.5$ & Sırık & $5-8$ & $\geq 2.0$ \\
Maden Direği & $8-22$ & $\geq 1.5$ & Çubuk & $\leq 4$ & $\geq 1.0$ \\
Yuvarlak Sanayi & $\geq 5$ & $0.5-1.4$ & & & \\
\hline
\end{tabular}

Ağaçların gövde şekli, alındığ 1 yer, çap, uzunluk, yıllık halka yapısı, öz ve diri odun oluşumu, özgül ağıllık, budak, reaksiyon odunu, reçine keseleri, lif kıvrıklığı ve çatlaklar gibi özellikler ve kusurlar, odunların kalite sınıfı üzerine etkili etmenlerdir. Bu nedenle, örnek ağaçlar üzerinde odun ürünleri sinıflaması yapılırken bunlara dikkat edilmiştir. Bilindiği üzere yetişme ortamının çok iyi olmadığı alanlarda Kızılçam gövde formu genellikle çok düzgün değildir. $\mathrm{Bu}$ yüzden yukarıdaki tabloya göre, ölçüleri tomruk sinifinda kalabilecek olan seksiyonların, gövde şeklinin eğriliği ve diğer odun kusurları sebebiyle 'Sanayi Odunu' veya "Yakacak Odun" içerisine dâhil edildiği durumlar olmuştur. Ayrıca Kızılçam

Smalian formülü gövdesinden 'Tel Direği' özelliklerini taşıyacak nitelikte çok düzgün direk ç1kmaması sebebiyle talep görmemekte, bu sebeple direk çeşidi olarak yalnızca 'Maden Direği’ üretilip pazarlanmaktadır. Bu yüzden sınıflandırmada direk çeşidi olarak 'Maden Direği' sınıfları kullanılmıştır.

$\mathrm{Bu}$ aşamada sınıflandırma yapılırken, Orman İşletmelerinin pazar payı da dikkate alınarak, sırık ve çubuk sinıfları 'Sanayi Odunu' sınıfına dâhil edilmiştir. Sınıflandırması yapılan örnek ağaçların, ürün çeşitlerine göre hacimleri bulunurken dip kısım için silindir (Denklem 1), uç parça için koni (Denklem 2) ve ara seksiyonlar için Smalian formülü (Denklem 3) kullanılmıştır.

$$
\begin{gathered}
V(k \ddot{u} t u ̈ k)=\frac{\pi}{4} d_{0.3}^{2} l \\
V(u c ̧)=\frac{1}{3} \frac{\pi}{4} d_{n}^{2} l \\
V(\text { seksiyon })=\frac{\pi}{4}\left(\frac{d_{0}{ }^{2}+d_{n}{ }^{2}}{2}\right) l
\end{gathered}
$$

Bu denklemlerde V: hacmi, $\mathrm{d}_{0}$ : seksiyonun kalın uç çapını, $\mathrm{d}_{\mathrm{n}}$ : seksiyonun uç çapını, $\mathrm{d}_{0.3}$ : kütük çapını, l: seksiyon ya da parça uzunluğunu ifade etmektedir. Çapların birimi cm, uzunluğun birimi $\mathrm{m}$, hacmin birimi $\mathrm{dm}^{3}$ olarak alınmıştır.

Çalışma kapsamında; kesilmiş olan 488 adet örnek ağacın tümünde; ağacın kesim yerinden tepeye kadar olan gövde, Tablo 3’teki ölçütlere göre sinıflandırılmıştır. Sinıflandırma yapıldıktan sonra sirasıyla;

1. Kesilen ağaçlarda yapılan gövde analizinde her bir seksiyonun kabuklu çap ve çift kabuk kalınlığı ölçülmüştür. Elde edilen ölçümlerle her bir ağacın kabuklu ve kabuksuz gövde hacmi elde edilmiş ve dolayısıyla her bir ağaçtaki kabuk oranları hesaplanmıştır.
2. Standartlara göre sınıflandırılmış olan odun ürün çeşitleri (tomruk, maden direği, sanayi odunu ve kabuk hacmi) her bir ağaç için yüzde olarak ayrı ayrı hesaplanmıştır.

$\mathrm{Bu}$ aşamalardan sonra, tespit edilen odun ürün çeşitleri oranlarıyla ağaçların göğüs çapları ilişkiye getirilerek regresyon analizleri yapılmıştır. Daha önce yapılan çalışmalara göre (Eraslan, 1954; Alemdağ, 1967; Sun ve ark., 1978; Asan, 1984), odun ürün çeşitleri üzerinde ağaç boyu etkisinin önemsenmeyecek kadar az olduğu tespit 
edilmiştir. Bu çalışmada da, boy değişkeni ölçülmüş olmasına rağmen, hem istatistiksel olarak önemli oranda katkısı olmadığından hem de kullanılması pratik olmayacağından bu oranların modellenmesinde boy faktörü dikkate alınmamıştır. Yapılan çalışmada yakacak odun hacim oranlarının tespitine ilişkin belirli bir model önerilmemiştir. Bunun başlıca nedeni; yetişme ortamı verimliliğinin iyi olduğu alanlardaki ağaçlarda yakacak odun yüzdesi normal bir seyirde azalmaktayken, yetişme ortamı verimliliğinin kötü olduğu alanlardaki ağaçlarda yakacak odun yüzdesi anlamsiz oranlarda artabilmesidir. $\mathrm{Bu}$ durumda da, biyolojik büyüme esaslarına uygun trendde bir eğri tespit edilememektedir. Bu yüzden; yakacak odun hacim oranı hesaplanırken; diğer odun ürün çeşitlerine (tomruk, maden direği ve sanayi odunu) ilişkin değerler, seçilen modellerle hesaplanmış, bu oranların toplamının \%100'den çıkarılmasıyla da yakacak odun hacim oranı elde edilmiştir.

Çalışma kapsamında odun ürün çeşitleri modellerinin oluşturulmasında; göğüs çapı ve gögüs çapından türetilen yeni değişkenler, odun ürün çeşidi oranlarıyla ilişkiye getirilmiş

\section{Belirtme Katsayıs1}

Tahminin Standart Hatas1

Hata Kareler Ortalaması ve istatistiksel olarak $p<0.05$ önem düzeyiyle ilişki gösteren değişkenlerle modeller oluşturulmuştur. Ayrıca, göğüs çapının türevleriyle yeni değişkenler türetilerek; SPSS (SPSS 15.0 Inc., Coakes, 2008) adlı istatistik paket programı yardımıla "İleri Doğru Seçim (Forward Selection)", "Geriye Doğru Seçim (Bacward Selection)" ve "Aşamalı Regresyon (Stepwise Selection)" yöntemleri vasitasıyla daha iyi modeller aranmıştır. $\mathrm{Bu}$ modellerde, ilgili ağaçların odun ürün çeşitlerinin kabuksuz hacimlerine karşılık gelen yüzde (\%) oranlarıyla; aynı ağaçların göğüs çapları $\left(\mathrm{d}_{1.3}\right)$ ilişkiye getirilerek regresyon analizleri yapılmıştır. Denenen modeller içinden; biyolojik büyüme esaslarına en uygun olduğu görülen, istatistiksel olarak $\mathrm{p}<0.05$ önem düzeyi ile anlaml1, belirtme katsayısı ( $\mathrm{R}^{2}$, Denklem 4) en yüksek ve tahminin standart hatası ( $S_{y . x}$, Denklem 5), en düşük olan model seçilmiştir.

Ayrıca çalışma kapsamında oluşturulan modellerle Sun ve ark. (1978) tarafindan oluşturulan modellerin kıyaslanmasında Hata Kareler Ortalamaları (Denklem 6) da hesaplanmıştır.

$$
\begin{gathered}
R^{2}=1-\left(\frac{\sum\left(\mathrm{Y}_{\mathrm{i}}-\widehat{\mathrm{Y}}_{\mathrm{i}}\right)^{2}}{\sum\left(\mathrm{Y}_{\mathrm{i}}-\overline{\mathrm{Y}}_{\mathrm{i}}\right)^{2}}\right) \\
\mathrm{S}_{\mathrm{y} \cdot \mathrm{x}}=\sqrt{\frac{\sum\left(\mathrm{Y}_{\mathrm{i}}-\widehat{\mathrm{Y}}_{\mathrm{i}}\right)^{2}}{\mathrm{~N}-\mathrm{p}}} \\
H K O=\frac{\sum\left(\mathrm{Y}_{\mathrm{i}}-\widehat{\mathrm{Y}}_{\mathrm{i}}\right)^{2}}{\mathrm{~N}}
\end{gathered}
$$

Burada, N: örnek sayını, p: parametre sayısını, $Y_{i}=$ örnek ağaçların hesaplanan $\%$ hacim oranını, $\widehat{Y}_{\mathrm{i}}=$ örnek ağaçların model ile tahmin edilen \% hacim oranını, $\overline{\mathrm{Y}}_{\mathrm{i}}=$ örnek ağaçların ölçülen ortalama \% hacim oranını göstermektedir.

\section{Bulgular ve Tartışma}

Tek girişli odun ürün çeşitleri oranlarını belirleyebilmek için, çalışma alanından kesilmiş olan 488 adet ağaç verisi kullanılmıştır. Tek girişli odun ürün çeşidi modellerinin belirlenmesinde bağıml değişken olarak ilgili ürün çeşidinin oransal değerleri; bağımsız değişken olarak da söz konusu ağaca ilişkin göğüs çapı $\left(\mathrm{d}_{1.3}\right)$ ile türetilmiş olan yeni değişken değerler kullanılmıştır. Çalışma kapsamında elde edilen modellerdeki tüm parametreler 0.05 önem düzeyine göre anlamlıdır.

Her bir ürün çeşidi için seçilen modellerin belirtme katsayıları $\left(\mathrm{R}^{2}\right)$ ve tahminin standart hataları $\left(\mathrm{S}_{\mathrm{y} . \mathrm{x}}\right)$, hesaplanmış ve Tablo 4'de, ayrıca her bir odun ürün çeşidinin çapa bağlı olarak değişimleri de Şekil 2-5'te verilmiştir. 
$\%$ Tomruk Hacmi

$\%$ Sanayi Odunu Hacmi

\% Maden Direği Hacmi

$\%$ Kabuk Hacmi

$$
\begin{aligned}
& \% V_{T}=117.55473-(1968.48094 / \mathrm{d}) \\
& \% V_{S}=90.31906 \times e^{(-0.07345 x d)} \\
& \log \% V_{M}=2.51337-0.00036 \times d^{2}-0.35221 \times \log \left(d^{2}\right) \\
& \log \% V_{K b k}=1.46289-0.00002 \times d^{2}-0.04764 x \log \left(d^{2}\right)
\end{aligned}
$$

Tablo 4. Odun ürün çeşidi modellerine ilişkin istatistiksel sonuçlar

\begin{tabular}{cccc}
\hline Odun Ürün Çeşidi & $\mathrm{R}^{2}$ & $\mathrm{~S}_{\mathrm{yx}}$ & $\mathrm{df}$ \\
\hline \% Tomruk Hacmi & 0.840 & 6.771 & - \\
\% Sanayi Odunu Hacmi & 0.700 & 7.500 & 1,0830 \\
\% Maden Direği Hacmi & 0.856 & 10.941 & 1.0630 \\
\% Kabuk Hacmi & 0.972 & 0.401 & 1.0002 \\
\hline
\end{tabular}

Sanayi odunu, maden direği ve kabuk oranlarını belirlemede seçilen modeller üssel modellerdir. Bundan dolayı ölçülen değerlerin sanayi odunu için doğal logaritması ve maden direği ile kabuk için ise logaritmaları alınmıştır. Doğal logaritma ve logaritma alınarak hesap yapılması nedeniyle oluşan sistematik hatanın giderilmesi için düzeltme faktörüne ihtiyaç duyulmaktadır (Spurr, 1952; Alemdağ, 1962; Akalp 1978). Seçilen modellere ait düzeltme faktörleri de, sanayi odunu modeli için Denklem 7 (Baskerville, 1972) ve maden direği ile kabuk modelleri için ise Denklem 8 'deki formüller kullanılarak hesaplanmış ve Tablo 4'de verilmiştir.

$$
\begin{aligned}
& f=e^{\frac{\mathrm{Syx}^{2}}{2}} \\
& d f=10^{1.1513 x \operatorname{Syx}^{2}}
\end{aligned}
$$

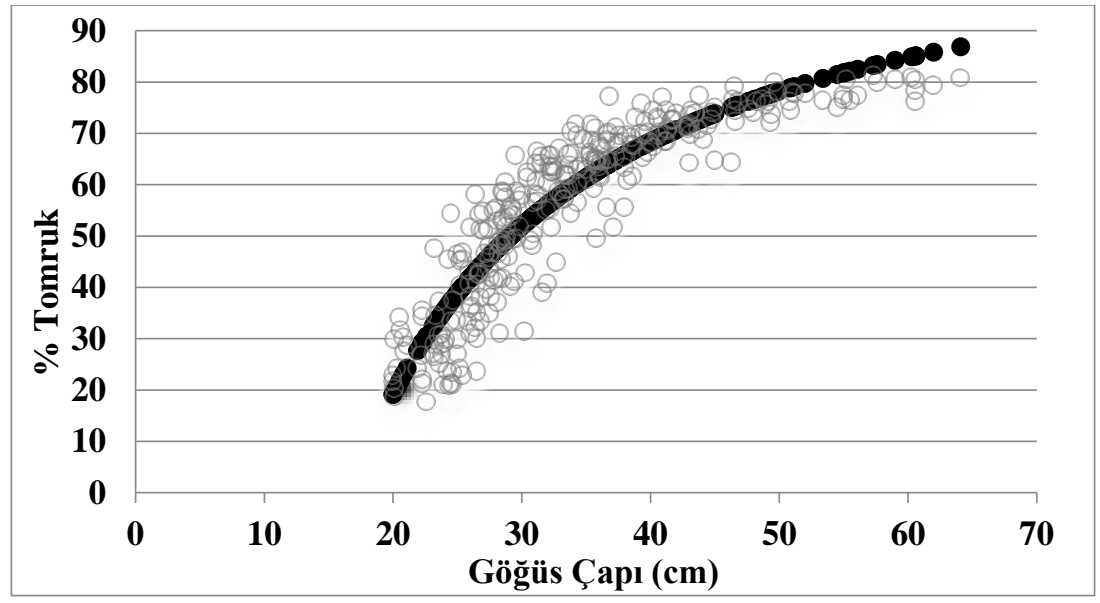

Şekil 2. Tek ağaç tomruk oranı ile gögüs çapı arasındaki ilişki 


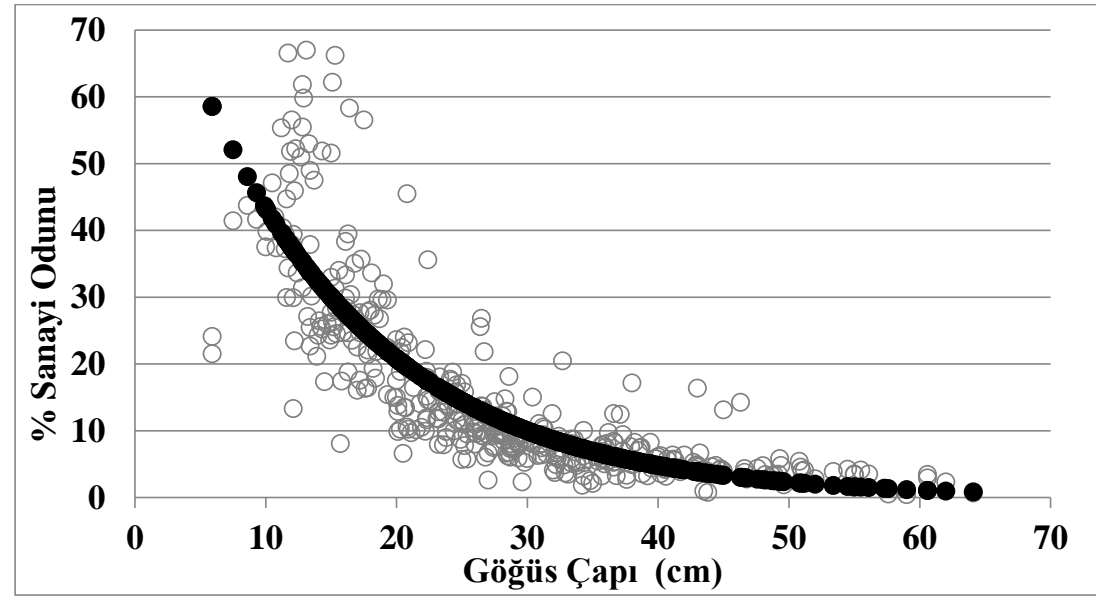

Şekil 3. Tek ağaç sanayi odunu oranı ile göğüs çapı arasındaki ilişki

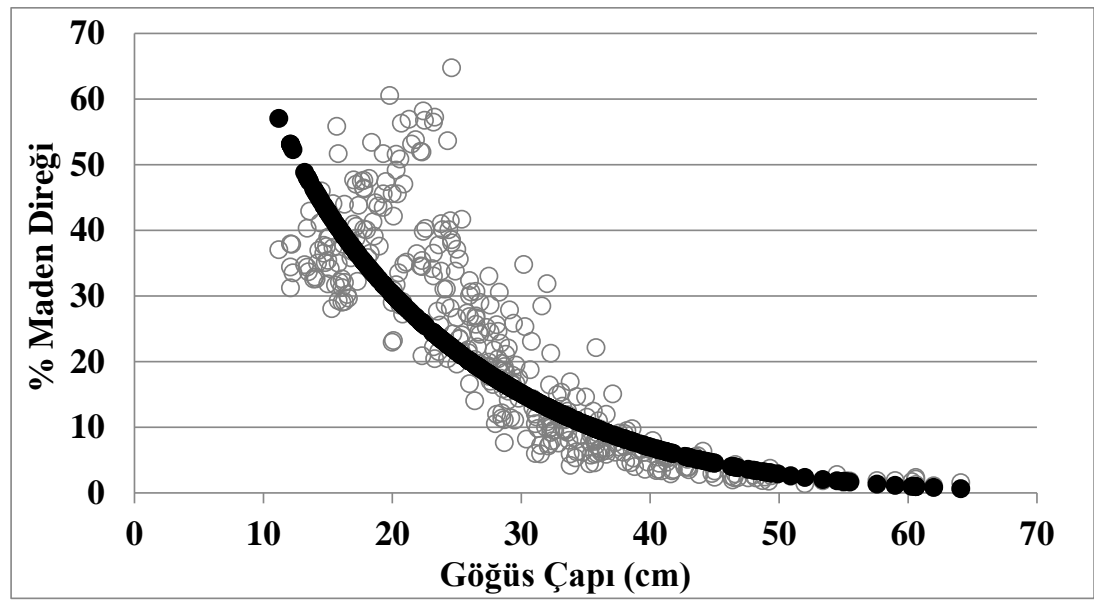

Şekil 4. Tek ağaç maden direği oranı ile göğüs çapı arasındaki ilişki

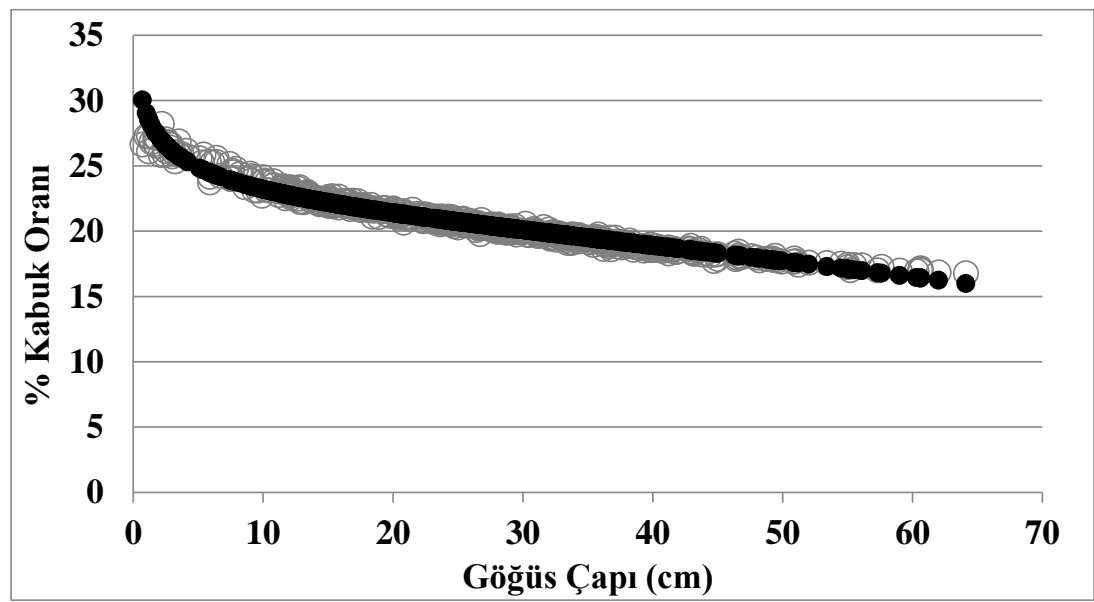

Şekil 5. Tek ağaç kabuk oranı ile göğüs çapı arasındaki ilişki

Üretilen tek girişli odun ürün çeşitleri modelleriyle, bir ağaçtaki tomruk, sanayi odunu, maden direği ve kabuk oranları hesaplanmış, bu değerlerin toplamının 100'den çıkarılmasıyla ağaçtaki yakacak oranı bulunmuş ve "Kızılçam Tek Girişli
Odun Ürün Çeşitleri Tablosu" oluşturulmuştur (Ek Tablo 1).

Ayrıca, çalışma kapsamında elde edilen Kızılçam tek girişli ürün çeşitleri modelleri; Sun ve ark. (1978) tarafindan, ülkemizdeki tüm Kızılçam meşcereleri için yapılmış olan 
tek girişli ürün çeşitleri modelleriyle kıyaslanmıștır. Bu kıyaslamalar, her odun ürün çeșidi için ayrı ayrı, yapılmıștır (Șekil 6$10)$.

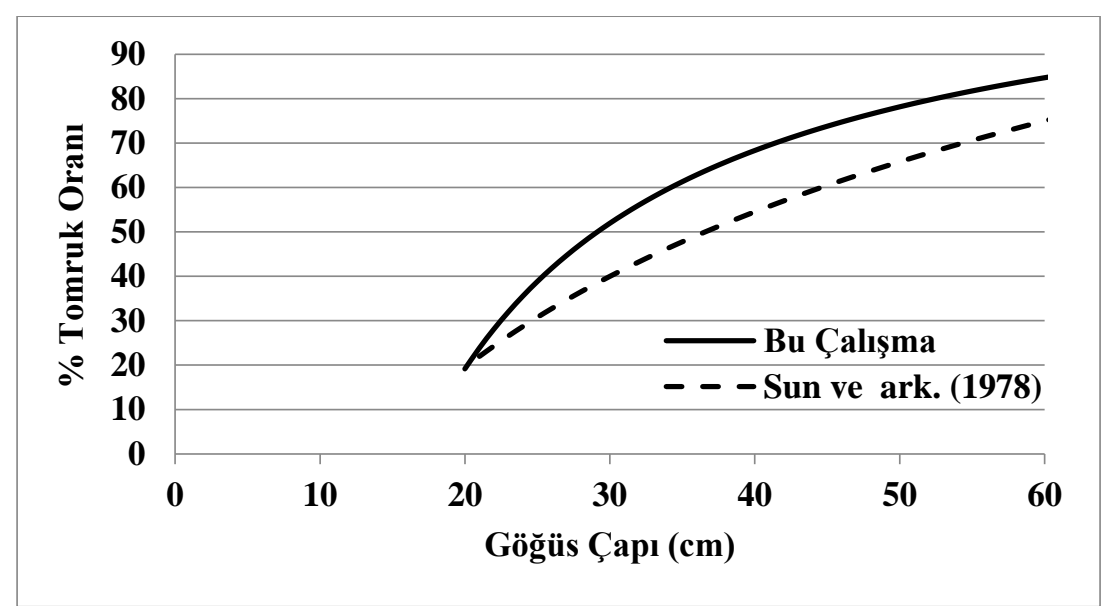

Şekil 6. Tek girişli modelle elde edilen tomruk oranlarının kıyaslanması

Şekil 6 incelendiğinde; çalışma kapsamında üretilen tek girişli 'Tomruk' oranı modelinin; Sun ve ark. (1978) tarafindan oluşturulan modelle aynı yönde, artış gösterdiği, ancak ona göre daha yüksek sonuç verdiği tespit edilmiştir. $\mathrm{Bu}$ durum model sonuçlarının elde edilmesinde kullanılan verilerden düşünülmektedir.

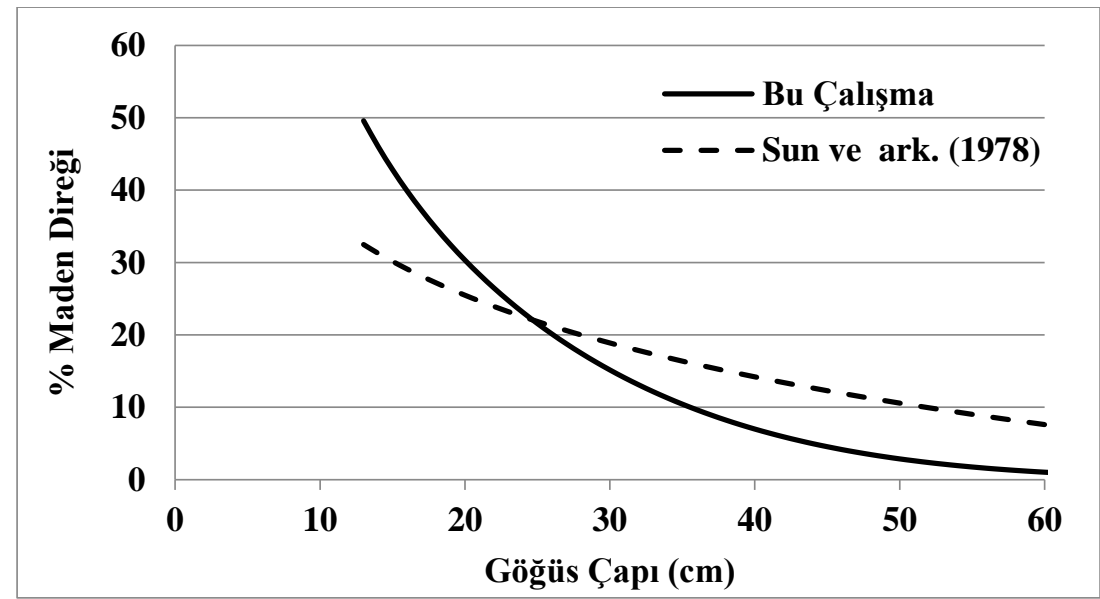

Şekil 7. Tek girişli modelle elde edilen maden direği oranlarının kıyaslanması

Şekil 7 incelendiğinde; çalışma kapsamında üretilen tek girişli Maden Direği oranına ilişkin modelin; Sun ve ark. (1978) tarafindan oluşturulan modelle aynı yönde, azalış gösterdiği ve 24 çapına kadar daha yüksek, bu çaptan sonra ise daha düşük sonuçlar verdiği görülmektedir. Zira $24 \mathrm{~cm}$ çap da, tomruk üretiminin yapıldığı çap kademesine yakın bir değerdir, bu durumda tomruk oranı fazlalaşması sebebiyle maden direği oranı azalması beklenen durumdur. 


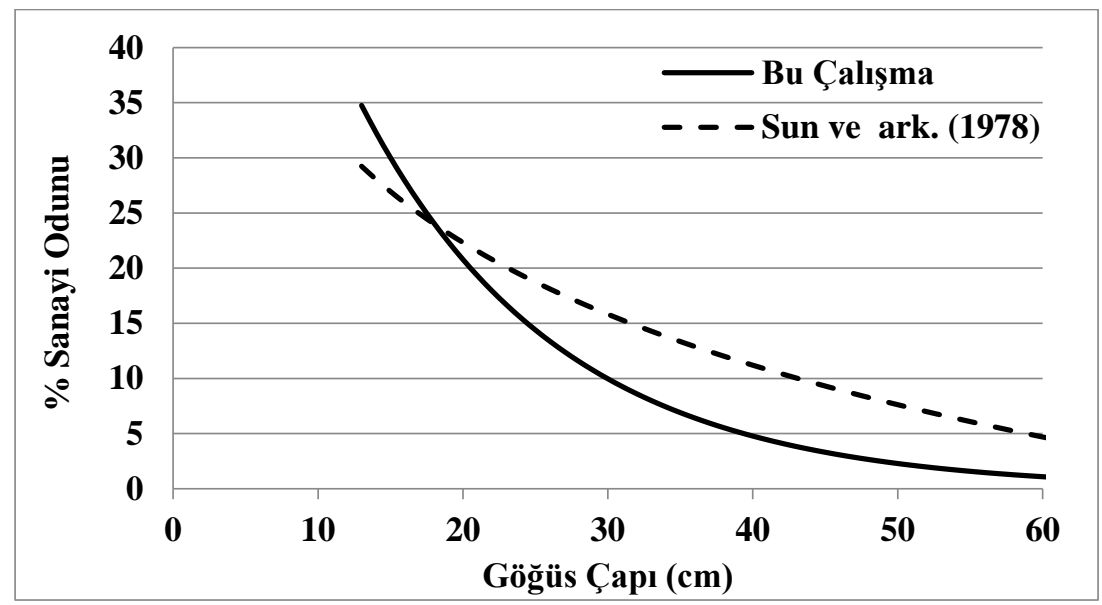

Şekil 8. Tek girişli modelle elde edilen sanayi odunu oranlarının kıyaslanması

Şekil 8 incelendiğinde; çalışma kapsamında üretilen tek girişli Sanayi Odunu oranına ilişkin modelinin; Sun ve ark. (1978) tarafından oluşturulan modelle aynı yönde olup, azalan bir seyir izlediği görülmektedir. Detaylı incelenecek olursa; çalışma kapsamında üretilen tek girişli sanayi odunu oranı modelinin, $15-25 \mathrm{~cm}$ çapları arasında Sun ve ark. (1978) tarafindan oluşturulan modele yakın, özellikle $18 \mathrm{~cm}$ çapından sonra ise sonrasındaki çaplarda ise daha düşük değerler verdiği görülmektedir, bu durum da, maden direği oranında da olduğu gibi tomruk üretiminin yapıldığı çap kademesi ve sonrasındaki çaplarda tomruk oranı fazlalaşması sebebiyle sanayi odunu oranı azalması normal karşılanmaktadır.

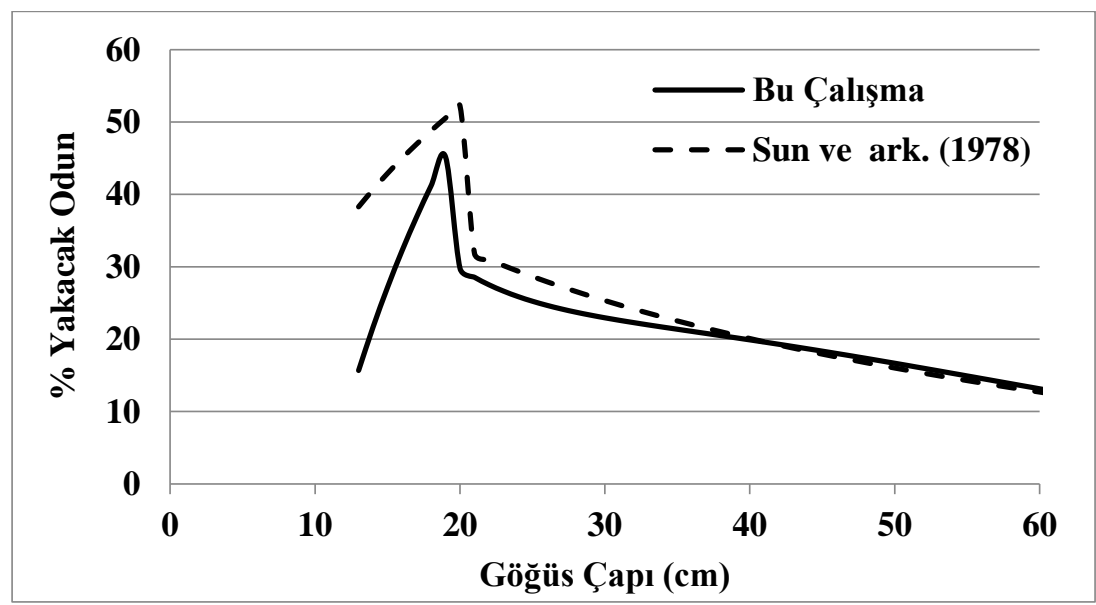

Şekil 91. Model sonuçlarına göre hesaplanmış yakacak odun oranlarının kıyaslanması

Şekil 9 incelendiğinde; çalışma kapsamında üretilen tek girişli modellerin farkı alınarak elde edilen yakacak oranı tablo değerleri; Sun ve ark. (1978) tarafindan yakacak oranı tablo değerleriyle aynı trendde seyretmektedir. Şekilden de görüleceği üzere; ağaçlardan odun ürün çeşidi olarak 'Tomruk' (yapacak odun) üretiminin gerçekleştiği çapa kadar (20 cm kabuklu çapına kadar) öncelikle artış göstermektedir. $20 \mathrm{~cm}$ kabuklu çaptan daha büyük çaplarda, odun ürün çeşidi olarak, tomruk da üretilmeye başladığı için, yakacak oranı giderek azalmaktadır. Her iki tablonun; yakacak oranı tablo değerleri $20 \mathrm{~cm}$ çapından sonra birbirine yakın, $35 \mathrm{~cm}$ çapında da daha da birbirine yaklaşmakta olduğu tespit edilmiştir. Şekil 9'da bariz olarak görülmektedir ki, tomruk üretiminin gerçekleştiği çap kademelerine yakın çaplarda yakacak odun oranı da keskin bir şekilde azalma göstermekte ve bundan sonraki çaplarda da daha yüksek oranda tomruk üretimine bağlı olarak yakacak odun oranı azalarak seyretmektedir. 


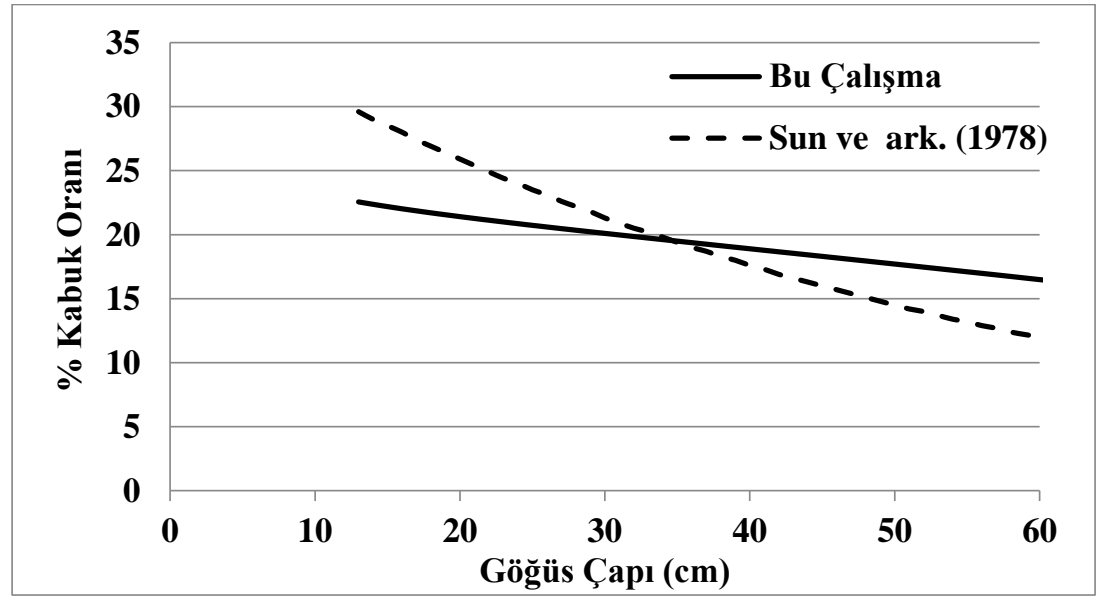

Şekil 10. Tek girişli modelle elde edilen kabuk oranlarının kıyaslanması

Şekil 10 incelendiğinde; çalışma kapsamında üretilen tek girişli kabuk oranı modelinin; Sun ve ark. (1978) tarafindan oluşturulan modelde olduğu gibi azalan bir seyir izlediği görülmektedir. $25-45 \mathrm{~cm}$ çapları arasinda Sun ve ark. (1978) tarafindan oluşturulan modele yakın (35 cm çapında neredeyse eşit); sonrasındaki çaplarda ise daha düşük değerler verdiği tespit edilmiştir. Kabuk kalınlığ 1 , çap arttıkça artıyor olmasına rağmen, kullanılan toplam odun hacmine oranı düşmektedir. Çünkü dolgun gövde hacmi oranının artmasına bağlı olarak, kullanılan odun hacmi, kabuk hacmi oranından daha fazla artış göstermektedir.

Çalışma kapsamında geliştirilen odun ürün çeşitleri modelleri ile Sun ve ark. (1978) tarafından geliştirilen denklemler arasında istatistiksel olarak anlaml fark olup olmadığının test edilmesi için eşleştirilmiş örneklem t-testinden yararlanılmış, ayrıca denklemlerin her birine ait 'Hata Kareler Ortalaması' hesaplanmıştır. Yapılan test sonucunda $\alpha=0.05$ önem düzeyine göre; tomruk, maden direği, sanayi odunu ve kabuk oranlarının her biri için farklılık tespit edilmiş (p değerleri sirasiyla; 0.000-0.010-0.0000.000 ) olup yalnızca yakacak odun oranı için farklilık tespit edilmemiştir $(\mathrm{p}=0.600)$. Zaten yakacak odun oranı da model vasitasiyla değil, modellerle hesaplanan diğer ürün çeşitlerinin 100 'den çıkarılmasılyla bulunmaktadır. Bu test sonucuyla, Sun ve ark. (1978) geliştirdikleri denklemlerin Mersin yöresinde kullanılamayacağ 1 sonucuna da varılmaktadır. Ayrıca çalışma kapsamında oluşturulan modellerin tomruk, maden direği, sanayi odunu, yakacak odun ve kabuk oranları tahmininde hesaplanan hata kareler ortalamalar1 sirasiyla 45.537-86.569-55.98192.290-0.163 iken; Sun ve ark. (1978) tarafindan oluşturulan modellerin hesaplanan hata kareler ortalamaları sirasiyla 184.494124.481-87.938-107.054-22.877 şeklindedir. Buradan da görülmektedir ki; çalışma kapsamında geliştirilen modeller ve oluşturulan tablo Mersin Yöresi için daha güvenilir sonuçlar vermektedir.

Çalışma kapsamında elde edilen ürün çeşitleri modelleri ile genel olarak Kızılçam için hazırlanmış olan modellerin seyrine uygun değerler elde edilmiştir. Çalışma kapsamında oluşturulan modeller, Sun ve ark. (1978) tarafından oluşturulan modellere göre; tomruk oranını daha yüksek, maden direği ve sanayi odunu oranları daha düşük miktarlarda tahmin etmektedir. Kiyaslanan modellerle arada bulunan değer farklılıklarının da, yapılan çalışmanın yöresel; diğer çalışmanın ise ülkemiz için genel olmasından kaynaklandığı düşünülmektedir.

\section{Sonuç}

Bu çalışma kapsamında, Mersin Yöresinde yayılış gösteren doğal, eşit yaşlı ve saf Kızılçam (Pinus brutia Ten.) meşcerelerinden kesilen örnek ağaçlar yardımıyla Mersin Yöresi saf Kızılçam meşcereleri için, tek girişli odun ürün çeşitleri modelleri geliştirilmiş ve bu modeller kullanılarak da 'Kızılçam Tek Girişli Odun Ürün Çeşitleri Tablosu' oluşturulmuştur (Ek Tablo 1).

Söz konusu tablonun oluşturulması için, Kızılçam meşcerelerinden alınan 243 adet 
geçici örnek alanı temsilen kesilen 488 adet ağaca (244 adedi göğüs yüzeyi orta ağacı ile 244 adedi galip ağaç olmak üzere) ilişkin ölçüm verileri kullanılmıştır.

Çalışma kapsamında düzenlenen tek girişli odun ürün çeşitleri modellerinin, literatür bilgileriyle uyumlu olduğu görülmüştür. Düzenlenen bu tablo vasitasiyla Mersin Yöresinde yayılış gösteren galip ve orta ağaç durumundaki Kızılçam ağaçlarında, sadece göğüs çap1 değerinin bilinmesiyle, kesim yapmaya gerek kalmadan odun ürün çeşitleri tespit edilebilecektir. $\mathrm{Bu}$ sayede özellikle dikili satıs uygulamalarında, firmalara satılan Kızılçam kesim sahalarından çıkacak olan odun ürün çeşitlerinin miktarı yaklaşık olarak belirlenebilecektir. Ayrıca çalışma kapsamında düzenlenen tek girişli odun ürün çeşitleri tablosu; Kızılçam meşcerelerinden elde edilecek olan odun ürün çeşitlerinin oransal olarak daha doğru bir biçimde bilinmesini ve meşcerelerden çıkarılacak bireylerin seçilirken bu durumun dikkate alınmasını da sağlayacak ve ekonomik planlamaya geçişte katkıda bulunabilecektir. $\mathrm{Bu}$ sayede; yanlış sınıflandırma ile odun hammaddesinde meydana gelebilecek değer kayıplarının da önüne geçilebilecektir. Bu yüzden, Kızılçamda odun ürün çeşitlerinin oransal dağılımının bilinmesiyle, en çok üretimi yapılan bu türümüzden daha çok verim alınabileceği düşünülmektedir. Buradan hareketle, diğer ağaç türlerinde yapılacak olan çalışmalarda odun ürün çeşitleri konusunun da araştırılması; orman işletmelerin ekonomik boyutu açısından gerekli ve önemlidir.

$\mathrm{Bu}$ çalışmanın benzerinin, diğer asli türlerimiz için de yöresel ve detaylı olarak yapılmasi; hem uygulayıcılara ve araştırmacılara 1şık tutacak, hem de ekonomik planlamaya geçiş için bir basamak oluşturacaktır.

Mersin Yöresi Kızılçam meşcereleri için düzenlenen tek girişli odun ürün çeşitleri tablosu, daha önce Sun ve ark. (1978) tarafından yapılmış olan çalışma kapsamında geliştirilmiş olan modeller ve düzenlenmiş olan tablo ile istatistiksel olarak farklilık bulunmaktadır. Bu durum model sonuçlarının elde edilmesinde kullanılan verilerden kaynaklanabileceği düşünülmektedir. $\mathrm{Bu}$ çalışmada hem orta ağaç hem de galip ağaçlardan elde edilen veriler kullanılmış olup mağlup ve ezilmiş ağaçların örneklenmemiş olmasından da kaynaklanmış olabileceği düşünülmektedir. Diğer taraftan Sun ve ark. (1978) tarafindan yapılan çalışmada hangi ağaçların örneklendiği, diğer bir ifadeyle sadece orta ağaçlardan mı yoksa meşçereyi temsil eden tüm ağaçlardan (mağlup-ortagalip ağaçlar) mı örnek alınıp alınmadığı bilinmemektedir.

Diğer taraftan ülke geneli için düzenlenmiş tabloların her yöre için uygun olmayıp test edilmeden kullanılmamalıdır. Bu yüzden, çalışma kapsamında düzenlenen Kızılçam Tek Girişli Odun Ürün Çeşitleri Tablosunun, Mersin dışındaki Kızılçam meşcerelerinde ya da farklı ağaç türleri için kullanılması mümkün olsa bile elde edilen sonuçların, tablodaki sonuçlarla uygun olup olmadığ kontrol edilmelidir. Bölgelerin iklim, toprak yapıs1 vs. gibi farklılıkları bulunduğundan dolayı, bu tablonun farklı yörelerde kullanılması halinde farklı1ıklar gösterebileceği bilinmelidir.

\section{Teșekkür}

$\mathrm{Bu}$ çalışmadaki verilerin elde edilmesi konusunda verdiği maddi destekten ötürü; Türkiye Bilimsel ve Teknolojik Araştırma Kurumuna (TÜBITAK-TOVAG Proje No:112O808; Proje adı: Antalya ve Mersin Yöresi Saf Kızılçam Meşcerelerinde Hasılat Araştırmaları) ve Mersin Orman Bölge Müdürlüğü personeline teşekkür ederiz.

Bu çalıșma, AÇÜ Fen Bilimleri Enstitüsü Orman Mühendisliği Anabilim Dalında tamamlanan "Mersin Yöresi Saf Kızılçam Meşcerelerinde Hasılat Araştırmaları" adlı doktora tezinin bir bölümünün özetidir.

\section{Kaynaklar}

Akalp, T., 1978. Türkiye'deki Doğu Ladini (Picea orieantalis Lk. Carr) Ormanlarında Hasılat Araştırmaları. Doktora Tezi, İstanbul Üniversitesi, Fen Bilimleri Enstitüsü, İstanbul.

Alemdağ, İ.Ş., 1962. Türkiye'deki Kızılçam Ormanlarının Gelişimi, Hasılat ve Amenajman Esasları. Ormancılık Araştırma Enstitüsü, Teknik Bülten No: 11, Ankara, $160 \mathrm{~s}$.

Alemdağ İ.Ş. 1967. Türkiye'deki Sarıçam ormanlarının kuruluşu, verim gücü ve bu ormanların işletilmesinde takip edilecek esaslar. Ormancılık Araştırma Enstitüsü Teknik Bülten No: 20, Ankara, 160s. 
Anonim 2015. Türkiye orman varlığg1. T.C. Orman ve $\mathrm{Su}$ İşleri Bakanlığı Orman Genel Müdürlüğü Orman İdaresi ve Planlama Daire Başkanlığ 1 , Ankara, 32s.

Anşin R. 1994. Tohumlu BitkilerGymnospermae (Açık Tohumlular)-I. Cilt-II. Bask1, KTÜ Orman Fakültesi Yayın No: 122/15, Trabzon, $262 \mathrm{~s}$.

Asan Ü. 1984. Kazdağı Göknarı (Abies equitrojani Aschers Et Sinten) ormanlarının hasılat ve amenajman esasları üzerine araştırmalar. İÜ Orman Fakültesi, 3205/365, İstanbul. İÜ Orman Fakültesi Dergisi, B Serisi, Cilt 43, Sayı 1-2, s. 3144, İstanbul.

Asmaz H. 1993. Akdeniz peyzajında kızılçamın önemi. Uluslararası Kızılçam Sempozyumu 18-23 Ekim, Bildiriler Kitab1, Marmaris, s. 48-55.

Baskerville, G., 1972. Use of Logarithmic Regression in The Estimation of Plant Biomass, Canadian Journal of Forest Research, 2, 49-53.

Coakes S.J. 2008. SPSS version 15 for windows: analysis without anguish, John Wily and Sons, Brisbane, $300 \mathrm{~s}$.

Eraslan İ. 1954. Trakya ve Bilhassa Demirköy Mıntıkası Meşe ormanlarının amenajman esasları hakkında araştırmalar. OGM Yayınları, Ankara, Sira No: 132, Seri No:13, 250 s.

Günay Z., Çancı F. 1982. Orman Ürünleri Standardizasyonu ve Kübaj., Saydam Matbaası, Ankara.

Kahriman A., Sönmez, T., Yavuz, M., Şahin, A., Yılmaz, S., Uzun, M., Kumaş, G., Genç, Y.,
2016, Antalya ve Mersin Yöresi saf Kızılçam meşcerelerinde hasılat araştırmaları, (TÜBİTAKTOVAG Projesi, Proje No: 1120808), Artvin Çoruh Üniversitesi Orman Fakültesi, Artvin (Basılmamıştır).

Kalıpsız A. 1982. Orman Hasılat Bilgisi. İstanbul Üniversitesi Orman Fakültesi Yayınları, No:3052/328, İstanbul. $349 \mathrm{~s}$.

SPSS Institute Inc., 2008. SPSS Base 15.0 User's Guide, 672 s.

Spurr, S.H. 1952. Forest Inventory, Ronald Press, New York. 476 s.

Sun O., Eren M. E., Orpak M. 1978. Temel ağaç türlerimizde tek ağaç ve birim alandaki odun çeşidi oranlarının saptanması. (TÜBİTAK, proje no: TOAG-288), Tarım ve Ormancılık Araştırma Grubu Yayını.

Şahin A. 2015. Mersin Yöresi Saf Kızılçam (Pinus brutia Ten.) meşcerelerinde hasılat araştırmaları, Doktora Tezi, Artvin Çoruh Üniversitesi, Fen Bilimleri Enstitüsü, Artvin, 331 s.

URL1 http://www.ogm.gov.tr/ekutuphane/Say falar/Istatistikler.aspx (20 Haziran 2016, 10:00).

URL2 http://www.mgm.gov.tr/veridegerlendir me/il-ve-ilceler-istatistik.aspx?m=MERSIN $\quad(17$ Mart 2015, 10:00).

Yeşil A. 1992. Değişik sıklık ve bonitetlerdeki Kızılçam meşcerelerinin yaşa göre gelişimi. Doktora Tezi, İstanbul Üniversitesi Fen Bilimleri Enstitüsü, İstanbul, 179 s. 
Ek Tablo 1. Kızılçam tek girişli odun ürün çeşitleri tablosu (\%)

\begin{tabular}{|c|c|c|c|c|c|c|c|c|c|c|c|}
\hline $\begin{array}{l}\text { Göğüs } \\
\text { Çapı } \\
(\mathbf{c m})\end{array}$ & & 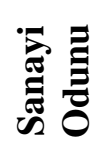 & 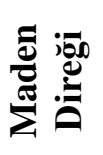 & 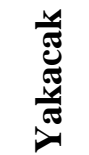 & 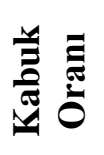 & $\begin{array}{c}\text { Göğüus } \\
\text { Çapı } \\
\text { (cm) }\end{array}$ & 告 & 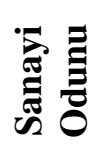 & 宽 & 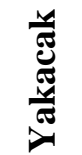 & 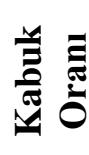 \\
\hline 11 & & 40.3 & 58.0 & 1.7 & 23.0 & 36 & \begin{tabular}{ll|}
62.9 \\
\end{tabular} & 6.4 & 9.6 & 21.1 & 19.4 \\
\hline 12 & & 37.4 & 53.5 & 9.1 & 22.8 & 37 & 64.4 & 6.0 & 8.9 & 20.8 & 19.3 \\
\hline 13 & & 34.8 & 49.6 & 15.7 & 22.6 & 38 & 65.8 & 5.5 & 8.2 & 20.5 & 19.1 \\
\hline 14 & & 32.3 & 46.0 & 21.7 & 22.4 & 39 & 67.1 & 5.1 & 7.6 & 20.2 & 19.0 \\
\hline 15 & & 30.0 & 42.8 & 27.2 & 22.2 & 40 & 68.3 & 4.8 & 7.0 & 19.9 & 18.9 \\
\hline 16 & & 27.9 & 39.9 & 32.2 & 22.0 & 41 & 69.5 & 4.4 & 6.4 & 19.6 & 18.8 \\
\hline 17 & & 25.9 & 37.2 & 36.9 & 21.9 & 42 & 70.7 & 4.1 & 5.9 & 19.3 & 18.7 \\
\hline 18 & & 24.1 & 34.7 & 41.2 & 21.7 & 43 & 71.8 & 3.8 & 5.4 & 19.0 & 18.5 \\
\hline 19 & 14.0 & 22.4 & 32.4 & 45.2 & 21.5 & 44 & 72.8 & 3.6 & 5.0 & 18.7 & 18.4 \\
\hline 20 & 19.1 & 20.8 & 30.3 & 29.8 & 21.4 & 45 & 73.8 & 3.3 & 4.5 & 18.3 & 18.3 \\
\hline 21 & 23.8 & 19.3 & 28.3 & 28.5 & 21.3 & 46 & 74.8 & 3.1 & 4.2 & 18.0 & 18.2 \\
\hline 22 & 28.1 & 17.9 & 26.5 & 27.5 & 21.1 & 47 & 75.7 & 2.9 & 3.8 & 17.7 & 18.1 \\
\hline 23 & 32.0 & 16.7 & 24.7 & 26.6 & 21.0 & 48 & 76.5 & 2.7 & 3.5 & 17.3 & 17.9 \\
\hline 24 & 35.5 & 15.5 & 23.1 & 25.9 & 20.9 & 49 & 77.4 & 2.5 & 3.1 & 17.0 & 17.8 \\
\hline 25 & 38.8 & 14.4 & 21.6 & 25.2 & 20.7 & 50 & 78.2 & 2.3 & 2.9 & 16.7 & 17.7 \\
\hline 26 & 41.8 & 13.4 & 20.1 & 24.7 & 20.6 & 51 & 79.0 & 2.1 & 2.6 & 16.3 & 17.6 \\
\hline 27 & 44.6 & 12.4 & 18.8 & 24.2 & 20.5 & 52 & 79.7 & 2.0 & 2.4 & 16.0 & 17.5 \\
\hline 28 & 47.3 & 11.6 & 17.5 & 23.7 & 20.3 & 53 & 80.4 & 1.8 & 2.1 & 15.6 & 17.3 \\
\hline 29 & 49.7 & 10.7 & 16.3 & 23.3 & 20.2 & 54 & 81.1 & 1.7 & 1.9 & 15.3 & 17.2 \\
\hline 30 & 51.9 & 10.0 & 15.1 & 22.9 & 20.1 & 55 & 81.8 & 1.6 & 1.7 & 14.9 & 17.1 \\
\hline 31 & 54.1 & 9.3 & 14.1 & 22.6 & 20.0 & 56 & 82.4 & 1.5 & 1.6 & 14.5 & 17.0 \\
\hline 32 & 56.0 & 8.6 & 13.1 & 22.3 & 19.9 & 57 & 83.0 & 1.4 & 1.4 & 14.2 & 16.9 \\
\hline 33 & 57.9 & 8.0 & 12.1 & 22.0 & 19.7 & 58 & 83.6 & 1.3 & 1.3 & 13.8 & 16.7 \\
\hline 34 & 59.7 & 7.4 & 11.3 & 21.7 & 19.6 & 59 & 84.2 & 1.2 & 1.1 & 13.5 & 16.6 \\
\hline 35 & 61.3 & 6.9 & 10.4 & 21.4 & 19.5 & 60 & 84.7 & 1.1 & 1.0 & 13.1 & 16.5 \\
\hline
\end{tabular}

